\title{
A PEDAGÓGUSKÉPZÉS KORSZERŰSÍTÉSE - EURÓPAI TENDENCIÁK
}

\author{
FALUS IVÁN \\ az Eszterházy Károly Főiskola kutatóprofesszora, a Tanárképzők Szövetségének \\ elnöke \\ falusivan@actel.hu
}

\begin{tabular}{l}
\hline A tanulmány sorra veszi az Európai Unióban a tanárképzéssel kapcsolatban megfogalmazott \\
legfontosabb irányelveket, és megkisérli feltérképezni, hogy ezek milyen mértékben hatják át \\
a pedagógusképzés hazai gyakorlatát. Az elemzés a következö szempontok mentén történik: \\
- a kompetenciák sajátosságai és szerepük a tanárképzésben; - tanárjelöltek felkészitése az \\
eltérö képességü, etnikumú, szociális hátterü tanulók nevelésére, oktatására; - az információs \\
és kommunikációs technológia alkalmazási lehetöségei a pedagógusképzésben; - a beveze- \\
tö szakasz jelentösége; - a képzö intézmények és az iskolák közötti partneri kapcsolat kiala- \\
kítása; - az iskola tanulóközösséggé válása; - a tehetséges fiatalok vonzása a pedagógus- \\
pályára; - a tanárok elömeneteli rendszerének kidolgozása; - a pedagógusképzök képzése.
\end{tabular}

Az Európai Unióban az elmúlt tíz esztendőben jelentős erőfeszítéseket tettek az oktatás és a képzés korszerüsítése, a tudásalapú társadalom megteremtése érdekében. Ezeknek az erőfeszítéseknek szerves részét képezték a pedagógusképzés korszerüsítése irányába tett lépések. A pedagógusképzés jelentőségének felismerését fémjelzi az a tény, hogy az Európai Unió által az oktatás és képzés területén létrehozott clusterek (az egyes országokat képviselő szakértői bizottságok) egyike a tanárok és oktatók kérdésével foglalkozik. A tanárok és oktatók klaszter megalakulása, 2005. óta 17 ülést tartott, amelyeken egy vagy több, a pedagógusképzés korszerüsítését érintő témát vitattak meg. A legfontosabbnak ítélt, a pedagógusokkal és a pedagógusképzéssel összefüggő kérdéseknek megbeszélésre külön tapasztalatcseréket (PLA) szerveztek, amelyeken a meglátogatott ország mutatta be a kérdéskörrel kapcsolatos gyakorlatát és eredményeit. Két-három ország képviselője pedig hozzászólásként bemutatta saját országának gyakorlatát. Az összes többi résztvevő megfogalmazta mind a vendéglátó ország, mind pedig a résztvevők által bemutatott néhány másik ország gyakorlatával kapcsolatosan a saját országában hasznosítható következtetéseket. A résztvevők ezen túl visszacsatolást is nyújtottak a rendező ország számára, hasznos tanácsokat adva a további fejlesztésekhez. Magyarország csak 2008 eleje óta vesz részt a szakértői bizottság munkájában, de információkkal rendelkezünk a korábbi munkálatokról is.

A jelen tanulmányban arra teszünk kísérletet, hogy a pedagógusképzés korszerüsítésével kapcsolatos néhány európai törekvést bemutassunk, elemezzünk és kö- 
vetkeztetéseket vonjunk le a magyarországi alkalmazás lehetőségére, célszerüségére vonatkozóan. A tanulmány keretében választ keresünk arra, hogy az elmúlt években bekövetkezett változások milyen mértékben követik az európai tendenciákat, illetve, hogy mely esetekben haladnak azokkal ellentétes irányba. Az elemzésre kerülő területek az alábbiak:

1. A kompetencia alapú pedagógusképzés megjelenése, a kompetenciák meghatározásának módja, a kompetenciák száma, jellege, a kompetenciák szerepe a pedagógusok alap- és továbbképzésének tervezésében, képzési folyamat értékelésében, a hallgatók munkájának segítésében, a pedagógusképzés módszereinek megújulásában.

2. A pedagógusjelöltek felkészítése a különböző felkészültségü, képességü, szociális hátterü, etnikai hovatartozású gyerekek együttes oktatására.

3. A korszerü információs és kommunikációs technológia alkalmazásának kiemelkedő szerepe van mind az iskolai tanítás gyakorlatában, mind pedig a pedagógusok szakmai fejlődésében, de elsajátításuk azt a célt is szolgálja, hogy a pedagógusok megfelelő szinten rendelkezzenek ezzel az általánosnak tekinthetö kulcskompetenciával.

4. A kezdő pedagógusokat segítő úgynevezett bevezető szakasz, bevezető képzés (induction period) megjelenése a pedagógusképzés európai gyakorlatában. A kezdő szakasz jelentősége, szerepe a pedagógusok beilleszkedésében, további szakmai fejlődésében.

5. A képző intézmények és a gyakorlás színhelyéül szolgáló iskolák együttmüködésének, partneri kapcsolatának kialakítása; az iskolák szerepe a képző intézménnyel szembeni elvárások megfogalmazásában, a képző intézmény és az iskola szakmai szemléletmódjának összehangolása, a közös tanulás, innováció és kutatás feltételeinek megteremtése.

6. Az iskolák tanulóközösségekké alakítása; a pedagógusok jelentős szakmai tudással rendelkeznek, amelynek hasznosítására az iskolán belül nagy lehetőségek kínálkoznak. Ehhez azonban ki kell alakítani azokat a feltételeket, amelyek között a pedagógusok képesek egymás munkáját elemezni, egymástól tanulni, közös innovációkban, kutató-fejlesztő munkában részt venni.

7. A tehetséges fiatalok pályára vonzása és a pályán történő megtartása, a pedagóguspályára kerülés különböző útjainak megteremtése. A magyarországi demográfiai hullámvölgy elfedi azt az Európában már élesen jelentkező tendenciát, hogy nem jelentkeznek kellő számban pedagóguspályára tehetséges hallgatók. (Ez a probléma már nálunk is jelentkezik a természettudományos tanárjelöltek esetében). A hamarosan bekövetkezhető pedagógushiány elkerülése érdekében növelni kell a pálya vonzerejét az érettségiző tanulók számára, de ezzel egyidejűleg biztosítani kell az egyéb pályákról a pedagógushivatás felé törekvő szakemberek rugalmas átképzésének a módjait is. 
8. A pedagógusok pályamodelljének, elömeneteli rendszerének kidolgozása; a jelenlegi monolit pedagógusszakmán belül különböző, a szakmai fejlettséget, a munka minőségét tükröző szintek (kezdő tanár, tapasztalt tanár, eredményes tanár, kiemelkedő szaktudású tanár) és a hozzájuk kapcsolódó kritériumok megjelenése. A pedagógusok egész életen át történő mentorálásának megvalósítása.

9. A tanárképzésben a szakemberek széles köre vesz részt, köztük a szaktudományok olyan művelői is, akik alapvető pedagógiai ismeretekkel sem rendelkeznek. Ugyanúgy, ahogyan a közoktatásban tanító pedagógusoknak, a pedagógusképzőknek, akik a pedagógusjelöltek számára modellként is szolgálnak, el kell sajátítaniuk a szakma müveléséhez elengedhetetlen kompetenciákat.

Tanulmányunkban a fenti, az európai fórumokon kiemelten kezelt és a hazai gyakorlat számára is jelentős tanulságokat ígérő kilenc kérdés megvitatására térünk ki, elsősorban az európai uniós dokumentumok és tapasztalatok felhasználásával.

\section{A kompetencia alapú tanárképzés}

Az EU külön szakértői bizottságot állított fel abból a célból, hogy ajánlásokat fogalmazzon meg az Európában folyó tanárképzés számára (Common, 2005). Talán könnyen belátható, hogy a közös kompetenciák megfogalmazása egyaránt elengedhetetlen feltétele a tanárok és a tanárjelöltek mobilitásának. Ugyanis, ha azt szeretnénk, hogy a hallgatók az EU különböző tanárképző intézményeiben folytathassák tanulmányaikat, akkor el kell érni, hogy ezek az intézmények legalább alapvető céljaikban, a tanárok által elérendő kompetenciák tekintetében ne térjenek el lényegesen egymástól. Ugyanígy, ha azt szeretnénk elérni, hogy a különböző országokban diplomát szerzett tanárok alkalmasak legyenek a többi országban pedagógusi munka végzésére, akkor a diploma megszerzésekor általuk birtokolt kompetenciáknak közelíteniük kell egymáshoz. A legfontosabb tanári kompetenciák közül a már idézett dokumentum (Common, 2005; A Tanács...2007) azokat emeli ki, amelyek alkalmassá teszik a tanárokat:

- átfogó kompetenciák fejlesztésére;

- olyan biztonságos és vonzó iskolai környezet kialakítására, amely a kölcsönös tiszteleten és együttmüködésen alapul;

- hatékony tanításra vegyes összetételü osztályokban, amelyekben különböző társadalmi és kulturális háttérrel, valamint a képességek és igények széles skálájával rendelkező tanulók vannak, ideértve a különleges nevelési igényü tanulókat is;

- $\quad$ szoros együttmüködésre munkatársakkal, szülőkkel és a tágabb közösséggel;

- arra, hogy részt vállaljanak annak az iskolának vagy képzőközpontnak a fejlesztésében, amelynek alkalmazásában állnak; 
- új ismeretek szerzésére és az innovatív magatartás elsajátítására reflektív gyakorlatban és kutatásban való részvételen keresztül;

- az információs és kommunikációs technológiák használatára különböző feladataik végrehajtása, valamint saját folyamatos szakmai fejlődésük során;

- arra, hogy önálló tanulóvá váljanak a pályafutásuk egészét végigkísérő szakmai fejlödés során.

Az egységes európai uniós állásfoglalásban a korszerü iskola müködtetéséhez ma legfontosabbnak látszó kompetenciákat emelik ki, míg a hazai fejlesztések ennél tágabb kört ölelnek fel, átfogóbbak. (A tanári mesterszakok ...2006; A tanárképzés...2006)

A kompetenciáknak a tanárképzésben nem csupán az a szerepük, hogy megjelölik a képzés általános céljait, hanem az is, hogy

- $\quad$ segítségükkel megítélhető a hallgatók felkészültsége;

- meghatározható a tantárgyak rendszere;

- hatnak a képzés módszereire;

- iránytüként szolgálnak a hallgatók számára, és ezzel növelik felelősségvállalásukat saját képzésükért;

- különböző utakon érhetők el, azaz növelik a képzöintézmények önállóságát;

- módot adnak a bevezető szakasz és a továbbképzés egyéni megtervezéséhez;

- szerepet játszanak a pedagógusképzés minőségbiztosításában.

A tanárképzés hazai gyakorlatában, a pedagógusképzéssel foglalkozó hazai szakemberek gondolkodásában az európai törekvésekkel egy időben, föként angol és amerikai hatásra megjelent a kompetenciák alkalmazásának az igénye (Falus, 2005/a; Falus és Kotschy, 2006), kidolgozásra került a hazai kompetencia-rendszer (A tanárképzés...2006) és hamarosan megjelent a törvényi szabályozás is (A tanári mesterszakok...2006). E fenti miniszteri rendelet nem sokkal később kiegészült az egyes tanári szakképzettségek speciális kompetenciáival is. A tanár szakindítási kérelmekben szerepel a kompetenciák jegyzéke, táblázatos formában látható az is, hogy az egyes tantárgyak mely kompetenciák elsajátításához járulnak hozzá, és minden tantárgyleírás elején szerepelnek az adott tantárgy segítségével elérhető kompetenciák. Ezt a bekezdést olvasva arra gondolhatnánk, hogy Magyarországon az európai törekvéseknek megfelelően bevezetésre került a kompetencia alapú tanárképzés. Formailag ez az állítás igaz lehet. A valós helyzet nem ítélhetö ilyen egyértelmủen pozitívnak, ugyanis már a miniszteri rendelet is egyenetlen. Az általános tanári kompetenciák megfogalmazása nem egyértelmü, a speciális kompetenciák némelyike csupán a szükséges ismeretek felsorolására korlátozódik, a szakindítási kérelmekben a kompetenciák gyakorta nem átgondoltak, nem töltik be a tantárgyi rendszer strukturálásában, a tananyag, a módszerek meghatározásában méltán elvárható szerepet. Mindennek a sebtében történő bevezetés az oka. Olyan szaktudósok kényszerültek megfogalmazni speciális kompetenciákat a rendelet számára, akiktől 
a tanulási eredményeken alapuló pedagógiai szemléletmód távol állt. A szakképzettség felelősök, a tantárgyfelelösök ugyancsak híján voltak a megfelelö felkészítésnek. Aligha tételezhetjük fel, hogy a bolognai-rendszerben akkreditált szakok, szakképzettségek a gyakorlatban megtestesítenék a kompetencia alapú képzés kívánalmait.

\section{A pedagógusjelöltek felkészítése a különböző felkészültségü, képességü, szociális hátterü, etnikai hovatartozású gyerekek együttes oktatására}

Ez a problematika felöleli a heterogén osztályokban történő eredményes tanítás kérdéseit, a differenciálásra történő felkészítés módjait, de ezen túlmutatva magában foglalja a speciális nevelésű igényü tanulók inkluzív oktatásához szükséges szakmai felkészítés kérdéseit is. Ez utóbbi probléma jelentőségét jól mutatja az a tény, hogy az Európai Unió külön ügynökséget hozott létre a speciális igényü tanulók problémáinak megoldására ${ }^{1}$. Az ügynökség 2009-ben indított programjának középpontjába az inkluzív nevelésben közreműködő tanárok képzésének kérdéseit állította. Jelenleg az inkluzív neveléshez szükséges tanári kompetenciaprofil kidolgozásán munkálkodik a 27 európai országból verbuválódott szakértői gárda. Hazánk aktív szerepet vállal ebben a fejlesztésben. Remélhetőleg az eredmények hamarosan gazdagítani fogják a hazai gyakorlatot.

A magyarországi iskolák között nagy különbségek vannak, az iskolákon belüli különbségek viszont viszonylag kisebbek, mint az EU más országaiban. Ezen a kedvezőtlen helyzeten, - azaz azon, hogy a tanulók esélyegyenlőtlenségeit jelentős mértékben növeli az iskolák közötti különbség, az a tény, hogy a családi háttér jelentős mértékben meghatározza, hogy milyen minőségü iskolába kerül egy tanuló feltétlenül változtatni kellene. A reménybeli társadalmi demokratizálódással minden bizonnyal együtt jár majd az iskolák közötti különbségek csökkenése, és ami ezzel együtt jár az iskolákon, osztályokon belüli különbségek növekedése. Ekkor viszont az iskoláknak és a bennük tanító pedagógusoknak alkalmasakká kell válniuk a heterogénebb tanulócsoportok oktatására.

Az EU tanárok és oktatók klasztere 2007 májusában, Oslóban tartott egy szakértői tanácskozást, tapasztalatcserét (PLA), amelynek témája az volt, hogy hogyan lehet felkészíteni a tanárokat a különböző kulturális hátterü osztályokban történő tanításra. Megállapították, hogy már az óvodai nevelök számára is szükséges ilyen felkészítés, és hogy az alapképzésen túl a folyamatos szakmai fejlödés egészében napirenden kell tartani ezt a kérdést. A találkozó résztvevői megállapították, hogy az általános tanári kompetenciák közül néhánynak különös szerepe van a heterogén osztályok tanítása során. Ezek a következők:

- a tantermi kutatási kompetenciák,

- a tanári tevékenység hatásának nyomon követése,

\footnotetext{
${ }^{1}$ http://www.european-agency.org/
} 
- kritikus reflexió a saját tevékenységére vonatkozóan,

- kollaboratív tevékenység.

Az általános képességeken túl fel kell vértezni a tanárokat olyan speciális képességekkel, mint:

- a más kultúrákkal szembeni attitüdök elemzése, átértékelése,

- az empátia fejlesztése,

- minden tanuló egyéniségként történő kezelése,

- minden tanuló számára siker biztosítása,

- az elöítéletek megfelelő kezelése az iskolában,

- a nyelvi hátrányok megfelelő kezelése,

- a kisebbségi tanulók által hozott értékek megfelelő felhasználása,

- a szülőkkel folytatott kultúraérzéken, hatékony kommunikáció (Report..., 2007).

Aligha beszélhetünk arról - a számos sikeres kezdeményezés ellenére -, hogy a hazai pedagógusok széles köre nem csupán hallana a fenti elvárásokról, hanem azok át is hatnák tevékenységét.

\section{Az IKT a tanárképzésben}

A 2007-ben megfogalmazott következtetések a tanárok számára legfontosabb nyolc kompetencia egyikeként említi azt, amely lehetővé teszi a tanárok számára, hogy hatékonyan alkalmazzák az IKT-t különböző oktatási feladataik megoldásában ugyanúgy, mint saját folyamatos szakmai fejlődésük elősegítésében (Következtetések... 2007). Az információs és kommunikációs technológia oktatási alkalmazását az „,Oktatás és képzés 2010” program kezdetétől fogva jelentősnek ítélték az európai uniós szakértők és maga a Bizottság is. Ezért létrehoztak egy klasztert az IKT oktatási alkalmazásával kapcsolatosan is. Hamarosan fel kellett ismerniük, hogy az IKT sikeres alkalmazása nem valósítható meg a pedagógusok megfelelő motiválása és felkészítése nélkül. Ezért igyekeztek kapcsolatot kiépíteni a Tanárok és Oktatók klaszterrel. 2009. június 24-én közös klaszterülésre és szemináriumra került sor, amelyen megállapították, hogy az IKT eredményes használatához elengedhetetlen:

- a tanárok IKT-vel szembeni pozitív attitüdjeinek kialakítása;

- az IKT-val kapcsolatos ismeretek, felkészültség nyújtása a pedagógusok alapképzésében és továbbképzésében;

- az IKT-vel kapcsolatos felkészítésben a technikai ismereteken túl az IKT alkalmazásával kapcsolatos korszerü pedagógiai szemlélet kialakítása, az egyéni és a kooperatív tanulás segítése az IKT segítségével;

- az IKT alkalmazása a tanárképzésben kreatív és innovatív módon valósuljon meg, ehhez megfelelő infrastuktúrát kell biztosítani, a tanárok igényeihez kell igazítani, jelentős számú blended learning; 
- tapasztalatot kell nyújtani, hogy az IKT az intézményen belüli és az otthoni egyéni tanulásnak is szerves része legyen (sokkal nagyobb szerepe van az IKT mindennapos alkalmazásának a tanárok felkészítésében, mint az IKTről szóló speciális ismeretek nyújtásának, gyakorlatok szervezésének).

A szeminárium résztvevői megállapították azt is, hogy 2001 és 2006 között eltelt öt évben jelentős mértékben terjedt az IKT alkalmazása az iskolákban, különösen abban a tekintetben, hogy annak alkalmazására nem csupán az informatika oktatásában, hanem a legkülönbözőbb tárgyak tanításában sor kerül. Lényeges a változás abban a tekintetben, hogy az eszközök alkalmazásának a tudatossága, célszerüsége, jelentős mértékben fejlődött. Az IKT alkalmazása azokban az esetekben válik hatékonnyá, ha ez és a digitális kompetencia a maga egészében részét képezi az intézmény stratégiájának, és ha egy egységes innovatív szemléletbe ötvöződik. Az IKT különösen eredményes lehet a személyre szabott tanulási módszerek támogatásában (Az IKT... 2009; Learning... 2010).

Az IKT az elmúlt években, hazánkban jelentős mértékben bevonult az iskolai gyakorlatba és a tanárképzésbe is. Ezen a területen azonban jelentős egyenetlenségek tapasztalhatók az eszközök kezelése és azok célszerü pedagógiai alkalmazása, az IKT oktatása és tantárgyi környezetben történő alkalmazása között.

\section{A bevezető szakasz}

A pedagógussá válás folyamata a képesítővizsgával nem ér véget. Az értelmiségi pályák jelentős részében a diploma megszerzését gyakornoki időszak, majd szakvizsga követi, s csak ezután tekintik teljes értékủ szakembernek a fiatal diplomást. Hazánkban - sok európai és amerikai országtól eltérően - a diplomás kezdő pedagógust egyenértékủnek tekintik évtizedes tapasztalatokkal rendelkező kollégájával. Ugyanolyan (esetenként még nehezebb) feladatokat kap, óraszáma ugyanolyan, személyre szóló segítséget, az igényeinek megfelelö továbbképzést ritkán bocsátanak a rendelkezésére, jóllehet kompetenciái nem teljesen kialakultak, teljesen új, szokatlan környezetbe került, elszakadt addigi kollégáitól. Ennek a feszültségektől terhes környezetnek a hatására alakul ki a kezdő pedagógusokat jellemző úgynevezett valóság sokk (Szivák, 1999; Szivák, 2004), amely sok pedagógust elriaszt a pályától, mások traumával terhelten folytatják munkájukat.

A kezdő szakasznak, a gyakornoki időszaknak sajátos szerepe van a pedagógussá válás folyamatában. Ekkor válik lehetővé az egyetemen szerzett propozicionális és procedurális tudásnak, valamint a mindennapi gyakorlatból származó eseti és gyakorlati tudásnak az összeötvözésére, híd verésére az egyetemi képzés és az iskolai gyakorlat közé. Európában sok helyütt jól képzett mentorok segítik a kezdő tanárt ebben az embert próbáló feladatban (Bleach, 1999; Falus, 2005/c; Tickle, 2000; TTA, 1998; Into 2003...). A kezdő tanár munkáját segítő mentor szerepével, kiválasztásával és képzésével részletesen foglalkozik Edgar Krull (Krull, 2004) magya- 
rul is megjelent tanulmánya. A kezdő tanárok mentorainak képzése Európa szerte időszerü feladat. 2009 végén fejeződött be a Comenius program keretében egy project, amelynek célja a kezdő tanárok mentorainak képzésére szolgáló tananyag és intenzív kurzus kidolgozása volt. A tananyagok 12 nyelven, közte magyarul is megjelentek, az intenzív kurzus nemzetközi közegben kipróbálásra került (www.tissnte.eu).

Az igényes mentorálás mellett a kezdő viszonylag könnyebb feladatokat kap, órakedvezményben részesül, megfigyelheti jó tanárok óráit, más iskolák tevékenységét, kapcsolatban áll más kezdő tanárokkal, a szükségleteinek megfelelő továbbképzésben részesül. Több országban, elsősorban az angolszász országokban, a kezdő, gyakornoki szakasz lezárásaként szakvizsgát tesznek, amely a véglegesítésnek elöfeltétele.

Érdemes egy európai ország, Angliai bevezetö képzési rendszerét kissé részletesebben szemügyre venni. Az egyetemektől független szervezetként létrehozott Tanárképzési Ügynökség (Teacher Training Agency, TTA, majd TDA Teacher Development Agency) nagy gondot fordít a frissen végzett tanárok, a pályakezdők minősítésére és a kezdő, bevezető, gyakornoki szakasz megszervezésére. 1998-ban fogalmazták meg a végzett tanár sztenderdjeit (TTA, 1998), egy évvel később pedig kidolgozták a kezdő szakasz szervezetét, müködési mechanizmusát, sztenderdjeit (Guidance, 2001) és a kezdő tanár munkájának megtervezését segítő úgynevezett pályakezdö profilt (Career Entry Profile, 1999). Az első két év tapasztalatait empirikus vizsgálat segítségével feltárták, elemezték (Totterdel és mtsai, 2002), majd javaslatot tettek előbb az alapképzési sztenderdek, majd a kezdő tanári sztenderdek valamint a pályakezdö és a szakmai fejlesztési profil új változatának kidolgozására (FitzPatrick és Soulsby, 2002).

Nagy-Britanniában, a kezdő szakasz jelenlegi rendszerében, a pályakezdő egy részletes útmutatót kap, amely közli vele az elérendő sztenderdeket és lehetőségeit (tutor igénybevétele, $10 \%$, Skóciában 30\% órakedvezmény, az egyéni szükségleteihez igazodó egyéni és közös szakmai fejlesztési program, a pályakezdő óráinak megfigyelése, elemzése, mások óráinak megfigyelése, értékelő megbeszélések, munkájának írásos értékelése, személyes segítő a pedagógiai intézetből), valamint kötelezettségeit az aktív közremüködésben és a célok elérésében (Into, 2003; Teacher Induction, 2004). A pályakezdő sztenderdjei olyan tanári kompetenciákat foglalnak magukban, amelyek a végzö tanárjelölt sztenderdjeire épülnek, de kialakításuk főként az iskolai munka keretében lehetséges: keresi és felhasználja a lehetőségeket a kollégákkal történő együttmüködésre, minden lehetöséget kihasznál szakmai fejlödése érdekében, megtervezi a különleges bánásmódot igénylő gyerekekkel történő foglalkozás módjait, megfelelő kapcsolatot alakít ki a szülőkkel, jól dolgozik csapatban, megfelelö fegyelmet biztosít a tanuláshoz.

A kezdö és szakmai fejlesztö profil egy olyan javaslatokból, értékelőlapokból és ürlapokból álló füzet, amely segítséget nyújt a pályakezdőnek és tutorának, valamint az iskolának ahhoz, hogy a pályakezdő a legmegfelelőbb támogatásban ré- 
szesüljön szakmai fejlődéséhez, az iskola pedig a legjobban kamatoztathassa a pályakezdő szakmai felkészültségét. A profilt még a képző intézmény bocsátja ki, feltüntetve rajta a pályakezdő felkészültségét a sztenderdekhez viszonyítva, majd ezekből és a pályakezdő sztenderdekből kiindulva a tutor és a pályakezdő együttesen megtervezik a pályakezdő szakasz céljait és az ezekhez eljuttató cselekvési tervet. Minden egyes cél tekintetében meghatározzák a teljesítés kritériumát, a szükséges tevékenységet, ennek feltételeit, a teljesítés időpontját, majd beírják az értékelést, a teljesítést. A kezdő szakaszban hat ellenőrzési pont van, amikor áttekintik mindegyik elérésére vonatkozóan a megtett lépéseket, az elért eredményeket, a szükséges további teendőket. Külön ürlapok szolgálnak a saját tevékenység értékelésre, a mások megfigyeléséből származó tapasztalatok rögzítésére, a tutorral folyatott megbeszélések rögzítésére.

A pályakezdő profil a bevezető szakasz szabályozásának, a reflektív, az önmagát állandóan fejleszteni kívánó tanári szemlélet kialakításának kiváló eszköze. Segítségével kapcsolatot lehet teremteni a pedagógussá válás alapképzésben elért eredményei és továbbképzés közé. A kezdő pedagógus fejlődésének tudatos irányítójává válik. A pályakezdés segítése előmozdítja az alapvető kompetenciák kialakulását, az önfejlesztő tanári magatartást, megteremti a sikeres pályakezdés feltételeit. Felgyorsíthatja azt a folyamatot, amely a pályakezdőt a tapasztalt tanárral azonos színvonalú munkára teszi alkalmassá.

A bevezető vagy kezdő szakasznak (induction period) az EU Bizottsága is nagy fontosságot tulajdonított, $\mathrm{s}$ annak bevezetését oktatáspolitikai szintre emelte (Következtetések, 2007; Következtetések, 2009; Snoek, 2009).

Az EU-s állásfoglalások a tanítás minőségének emelése érdekében kívánatosnak ítélték az alap-, a bevezető és a továbbképzés egységes, egymásra épülő, koherens rendszerének kialakítását. A bevezető szakasznak két szempontból is kiemelkedő a szerepe: itt vértezhetők fel a kezdő pedagógusok az eredményes munkához nélkülözhetetlen kompetenciákkal, és az itt megjelenő segítségnyújtással jelentősen csökkenthető a pályaelhagyók száma, amely ténynek közvetlenül is mérhető gazdasági haszna is van. Az EU által szervezett szakértői csoportok közül a Teacher and Trainers klaszter 2008 októberében PLA-t szentelt a bevezető szakasz kérdéseinek, majd az ott elfogadott állásfoglalás alapján, egy szükebb szakértői csoport a bevezető szakasz rendszerszintủ és általános európai bevezetése érdekében összeállított egy kézikönyvet oktatáspolitikusok számára (Snoek et al, 2009).

A továbbiakban e kézikönyv megállapításai alapján hívjuk fel a figyelmet a bevezető szakasz lényeges jellemzőire, mutatjuk be az európai helyzet sajátosságait. A bevezető szakasz egyaránt érdeke a kezdő tanárnak, az őt alkalmazó iskolának és a pedagógusképző intézménynek. Az európai tanárszakszervezet (ETUCE) az alábbi követeléseket fogalmazta meg a kezdő szakasszal kapcsolatosan:

- támogatás a mentortól és a többi kollégától,

- csökkentett óraterhelés a bér csökkenése nélkül, 
- hozzáférés a munkát segítő forrásokhoz,

- különféle segítő programok látogatásának lehetősége,

- az elmélet és a gyakorlat összekapcsolásának szervezetileg biztosított lehetöségei.

Jelenleg hozzávetőlegesen az európai országok felében valósul meg a bevezető szakasz olyan módon, hogy a fenti elvárások mindegyike érvényesülne. Van, ahol az első egy-két évben a kezdő tanárt mentor segíti, van ahol kötelező képzésben kell részt vennie stb. Eltérések tapsztalhatók abban a tekintetben is, hogy a beveztö képzés előfeltétele-e a pályán történő alkalmazásnak, és hogy azt valamilyen formális értékelés követi-e.

A bevezető szakasz során háromféle segítségre van szüksége a kezdő pedagógusnak: a személyes segítség célja a tanári identitás kialakulásának elősegítése, a társas segítés célja az, hogy a tanár az iskolai közösség, a szakmai közösség egyenrangú tagjává váljon, és végül a professzionális segítség a szakmai készségek, képességek, kompetenciák kialakulását segíti.

A fenti három segítség, négy egymással összekapcsolódó rendszeren keresztül valósul meg. A mentorálás egy az iskolában tanató tapasztalt tanár segítségét jelenti, a kortársak segítsége oly módon valósul meg, hogy kezdő tanárnak lehetősége van más iskolákban tanító kortársaival is megosztani gondjait, a szakértői segítség szemináriumokon, az egyetemi oktatókkal folytatott személyes konzultációk útján valósul meg, míg az önreflexiós rendszer, amelyet különböző rögzítő eszközökkel, portfólióval, sztenderdekkel stb. kell támogatni.

A bevezető szakasz abban az esetben lesz eredményes, ha célszerủen összehangolják az abban szerepet játszó személyek és szervezetek feladatait. A kezdő tanáron, a mentoron, az iskolavezetésen, az iskolafenntartón, a pedagógusképzőkön, a minisztériumon kívül a szakmai szervezeteknek és a szakszervezeteknek is szerepük lehet a bevezető szakasz sikerességében.

A kézikönyv részletesen ismerteti hat egymástól lényegesen eltérő bevezetési gyakorlatot képviselő ország (Ciprus, Észtország, Hollandia, Írország, Norvégia, Skócia) rendszerét, ismerteti a témára vonatkozó kutatási eredményeket, és sorra veszi azokat a szempontokat, amelyeket egy ország oktatáspolitikusainak, tanárképzési szakembereinek célszerü mérlegelni, mielőtt kialakítják az adott ország bevezető szakaszának rendszerét (Snoek et al, 2009).

Hazánkban a tanári mesterszak 5. félévében a hallgatók egy iskolában gyakorolnak. Ez a gyakorlat jelentős lépést jelent a pedagógusképzés gyakorlatiasabbá tétele tekintetében, azonban semmiképpen sem helyettesítheti az Európában szokásos egyéves bevezető szakaszt. Az 5. féléves gyakorlat során sokkal kisebb a jelölt óraterhelése, nem a majdani munkahelyén dolgozik stb.

A három éves gyakornoki időszak viszont nem nyújtja azokat a feltételeket, amelyek a bevezető szakaszra jellemzőek, hiányzik a kezdő tanár órakedvezménye, az elsajátítandó kompetenciák leírása, az alapos mentorálás. 


\section{Partneri kapcsolat a pedagógusképzők és az iskolák között}

A képző intézmények és az iskolák közötti partneri kapcsolat kialakításának jelentőségével a klaszter 2007. októberi Dániában és Svédországban megtartott szakértői tanácskozása foglalkozott. Egyértelmüen arra a következtetésre jutottak, hogy a partneri kapcsolat minden résztvevő fél számára előnyökkel jár. Hozzájárul a tanárok alap- és továbbképzése minőségének javításához és az iskolákban folyó oktatónevelő munka színvonalának emeléséhez, az iskolában folyó innováció és fejlesztés támogatásához. A partneri kapcsolat eredményességének feltétele az, hogy az egyenlő felek kapcsolatán alapuljon, és gyakorlati problémák megoldását tekintse céljának. A partneri kapcsolatok létrejöttét elősegíti az, ha az iskolák finanszírozási rendszere és a pedagógusképzők akkreditációs rendszere támogatja azt.

Az európai tanárképzés gyakorlatában a megfelelő partneri kapcsolat kialakulásának számos akadályát tapasztalják: az iskola passzív szerepet tölt be, nem egyenrangú a kapcsolat, nem ismerik fel az iskolai innovációban betöltött szerepet, bizalmatlanság, elöítélet tapasztalható mind a két fél részéröl, nagy a távolság az elmélet és a gyakorlat között.

Az együttmüködés célja a tanítás és tanulás minőségének javítása a tanárok számára folyamatos szakmai fejlődés megteremtése és a kutatás megfelelő körülményeinek a megteremtése.

Az együttmüködés az iskola számára azzal a haszonnal jár, hogy aktívan részt vehet a pedagógusképzés folyamatában, saját tanárai továbbképzésben részesülnek, növekszik az iskola innovációs és tudásteremtő képessége a tanárképzők és a tanárjelöltek fejlesztő, kutató munkája révén, visszacsatolják a kutatási eredményeket az iskola gyakorlatába.

A tanárképző intézmény számára hasznos lehet az, hogy a tanárképzési program és az iskolai gyakorlat igényei között szorosabb kapcsolat jön létre, a tanárjelöltek számára valóságos, de a képző intézménnyel azonos szemléletet tükröző tanulási környezetet sikerül biztosítani, valóságos és releváns kutatási kérdések fogalmazódnak meg a tanárjelöltek számára.

A tanárjelöltek számára hasznos, hogy a valóságos iskolai munkában való részvétel megóvja őket a későbbi „valóság sokk”-tól, reálisabb képet alakítanak ki majdani szerepükről, sokféle tevékenységben vesznek részt az iskolai munkában.

Az egész rendszer számára előnyös az, hogy minden eddiginél koherensebb kapcsolat jön létre a tanárképzés különböző elemei, valamint a szakmai fejlődés, innováció és kutatás között.

Az együttmúködés sikeres megvalósításának feltétele az, hogy a kapcsolat mind az intézmények, mind pedig a tényleges résztvevők szintjén megvalósuljon. Elengedhetetlen a feladatmegosztás pontos szabályozása az együttmüködési szerződésben, és az, hogy rendszeresen megállapodjanak a konkrét együttmüködési feladatokban. 
Az európai tendenciáknak megfelelő partneri kapcsolat megteremtése a mesterszintủ tanárképzés 5. szemeszterében megvalósuló iskolai gyakorlat sikerességének elengedhetetlen feltétele. A kapcsolat szabályozására vonatkozóan hasznos elgondolásokat fogalmaz meg az OKM szakértői csoportja által összeállított ajánlás (Ajánlás...2009).

\section{Az iskolák, mint tanulóközösségek}

A Tanárok és oktatók klaszter hamar felismerte azt a tényt, hogy a pedagógusok saját szervezetükben, az iskolában folyó közös tanulása az iskola fejlődésének, a pedagógusok folyamatos képzésének az egyik leghatékonyabb módja. Ezért már 2006-ban, Hollandiában szakértői tanácskozást szerveztek a témában (Report... 2006). A résztvevők megállapították, hogy jelentős számú kutatás foglalkozik a tanuló szervezetek, tanuló közösségek, a szervezeti tanulás, a csoportban folyó tanulás, a kooperatív tanulás kérdéseivel, amelyek mind közel állnak az iskolai tanulóközösségek problematikájához.

A tanulóközösségek létrejöttének feltételeihez hozzá kell járulni mind országos szinten, mind az iskolafenntartók, mind pedig az iskolavezetők szintjén, és az is szükséges, hogy a tanárok rendelkezzenek az iskolai közösségben történő tanulás kompetenciáival.

A tanulóközösséggé válás hosszantartó folyamat, amely a feltételezi az iskola teljes kultúrájának átalakulását, amelyben az iskolavezetésnek kiemelkedő szerepe van. Át kell tekinteni az iskola adott helyzetét, feladatait, a közösség és az egyének felelősségét a célok elérésében. A tanárok megfelelő motivációja elengedhetetlen, világossá kell tenni a tanárok számára, hogy a tanulóközösség elősegíti egyéni tanulásukat és szakmai fejlődésüket is. Feltétlenül ki kell építeni a kölcsönös segítés, mentorálás módozatait. Ugyancsak a tanulás lényeges feltételei közé kell sorolnunk a hibázás lehetőségét. Csak a hibázást elfogadó légkör kedvez az innovációnak, a kezdeményezéseknek.

Ezen feltételek kialakítása érdekében az iskolavezetés számára megfelelő segítséget kell nyújtani, a tanárokkal szemben magas szintü elvárásokat kell támasztani, és az így kialakított igényeik kielégítésére kell, hogy szolgáljon a közös tanulás. Az egyéni igényekhez történő igazodás nagyfokú rugalmasságot is feltételez, hiszen az egyes pedagógusok és az egyes iskolák is eltérő szinten vannak, amelyek különböző megoldásokat igényelnek.

Az iskola tanítóközösségből tanulóközösséggé válása a tanulók önállóságának fejlődését is elösegíti.

A tanulóközösségek gondolata nem idegen a hazai iskolák gyakorlatától sem. Elegendő az önfejlesztő iskolák mozgalmára, vagy a referencia iskolák napjainkban kialakuló hálózatára gondolnunk. Megfelelő szakmai támogatással ez a hálózat az iskolai innovációk és a pedagógusok szakmai fejlődésének katalizátora lehet. 


\section{Alternatív utak a tanári pályához}

Hazánkban mostanáig nem jelentkezett jelentős tanárhiány az iskolákban, így nem is vetődött fel általánosságban annak az igénye, hogy más szakterületekről rövidített utakon biztosítsunk belépési lehetőséget a tanári pályára.

Az elmúlt években azonban mind markánsabban kirajzolódik annak a veszélye, hogy a természettudományos tanári szakképzettségek területén a közeli jövőben súlyos tanári hiánnyal kell szembenéznünk. A természettudományos tanári szakképzettségekre minimális számban jelentkeznek hallgatók, és az is kérdéses, hogy mindannyian a tanári pályán fognak-e elhelyezkedni. Több nyugat-európai országban ez a tanárhiány már érződik. Az oktatásirányítás több más intézkedés mellett, ezekben az országokban keresi azokat az utakat, amelyeken keresztül más szakterületről a tanári pályára lehetne vonzani szakembereket. A jelenlegi gazdasági válság ebben a tekintetben kedvezö feltételeket teremtett, mivel informatikusok, mérnökök munkahelyei szüntek meg, s közülük többen fordultak az oktatás felé.

Az EU-klaszter tervbe vette, hogy a közeli jövőben egy PLA-t szentel a kérdésnek. Ezt megelőzően tájékoztatást hallgatott meg az angliai megoldási módokról. Angliában számos út vezet a tanári pályára, amelyek igyekeznek megfelelö feltételeket biztosítani az eltérő képzettséggel, szakmai gyakorlattal, sajátos élethelyzettel rendelkező jelentkezők számára. Mindegyik programra jellemző, hogy elméleti és minimum 18 heti gyakorlati részt tartalmaz, és mindegyik tanári képesítéshez (képzett tanári státus, qualified teacher status) juttatja el a résztvevőt. Ez ugyanis feltétele az állami iskolákban történő tanári munkavégzésnek.

Az egyes utak a következök:

1. Érettségit követő három vagy négy éves tanárképzés, amely BA vagy BSc fokozatot ad.

2. A szaktudományos diploma megszerzése után két alapvető út kínálkozik:

- Az egyetemek és föiskolák által biztosított egy avagy két éves, gyakorta távoktatási jellegủ képzés (PGCE - Postgraduate certificate in Education), illetve;

- Az egymáshoz közeli iskolák közösségei által biztosított iskolaközpontú képzés (SCITT - School centered initial teacher training), amelyeken tapasztalt gyakorló pedagógusok tanítanak.

3. További három utat jelentenek a munka melletti képzési formák azok számára, akik már iskolában dolgoznak. Ennek három változata van:

- GTP - Graduate Teacher Programme föként már más szakterületen tapasztalatot szerzett diplomások számára, akiket már az iskolák alkalmaznak, és a tanári pályára szeretnének átállni.

- RTP - Registered Teacher Program szaktudományos és tanári képzést is nyújt valamilyen szaktudományos területen tanulmányaikat még be 
nem fejezett személyek számára, akik már iskolában dolgoznak, és a munka mellett szerzik meg szaktudományos és tanári képesítésüket is.

- Teach First - kiemelkedő diplomás szakembereknek tanári és vezetési felkészitést is adó munkamelletti képzés.

4. Értékelésre épülő képzés - már iskolában tanító, tanári képzettséggel nem rendelkező tapasztalt személyek számára, akik elsősorban portfólióval bizonyítják felkészültségüket.

5. Tengerentúlon képzett tanárok programja - képzett tanárok számára ad segítséget az angliai tanári licensz megszerzéséhez.

A bolognai-rendszerü tanárképzés bizonyos rugalmasságot hordoz magában, hiszen a tanári modul megszerzésére mód nyílik a szakos mesterszak elvégzése után is. A munka mellett megszerezhető tanári képzési formáknak azok a változatos formái, amelyek az angol rendszerben megjelentek, nálunk még nem ismertek. A természettudományos tanárhiányt megelőzendő, célszerű volna a pedagógusképző intézményeknek és az iskoláknak ezekre a formákra is felkészülniük. Természetesen az a számos csatorna csak abban az esetben müködik, ha sikerül a tanári pályán történő elhelyezkedést vonzóvá tenni.

\section{A folyamatos szakmai fejlődés, pályamodell, előmeneteli rendszer}

Az EU különféle állásfoglalásaiban, következtetéseiben nyomatékosan hangsúlyozza a pedagógusok egész életen át tartó szakmai fejlődésének fontosságát, annak biztosítását, hogy a pedagógus képes legyen felismerni saját fejlődésének eredményeit és a további fejlesztési igényeket is. Az egész életen át tartó fejlődés a továbbképzéseken kívül rendszeres mentorálást is kíván biztosítani (A tagállamok... 2007).

$\mathrm{Az}$ EU tagállamainak egy részében az ismertetett EU-s álláspontoknak megfelelően, már kidolgozták, és sikerrel alkalmazzák a pedagógustól elvárt kompetenciák rendszerét, s ezekre építve azokat a sztenderdeket, amelyek alapján a pedagógusok egész pályájuk során képesek felmérni adott helyzetüket, és a további szakmai fejlödésük érdekében megteendö lépéseket. Ezek a sztenderdek egyszersmind alkalmasak a pedagógusok önképzésének beszámítására, a pedagógus-értékelés kritériumaiként szolgálhatnak, és tekintetbe vehetők a pedagógusképző intézmények minőségbiztosítása során is. A sztenderdekre épülö pályamodell alkalmas a pedagóguspályán belül minőségi kategóriák kialakítására, és ehhez kapcsolódó bérezési kategóriák létrehozására is. Tíz európai ország tapasztalatait figyelembe véve az Eszterházy Károly Főiskolán a TÁMOP 4.1.2. B project keretében jelenleg folyik egy olyan, a sztenderdekre épülő, az európai tapasztalatokat a hazai körülményekhez igazító előmeneteli és értékelési rendszer kidolgozása. Ettől a pályamodelltől azt várjuk, hogy a pedagóguspályát az eddiginél vonzóbbá teszi, folyamatos motivációt biztosít a tanárok szakmai fejlödése, önképzése, minőségi munkavégzése érdekében. 


\section{A pedagógusképzők kompetenciái}

Pedagógusképzőknek gyakorta - tévesen - a pedagógiai, pszichológiai, tantárgypedagógiai tárgyak oktatói szokták nevezni. Valójában a pedagógusok képzéséért mindazok a személyek felelősek, akik a pedagógusképzés során a hallgatók szakmai fejlődését elősegítik, s őket, mindannyiukat pedagógusképzőknek kell tekintenünk.

Egyre több kutatás bizonyította azt a tényt, hogy a hallgatók tanárrá válását, szakmai kompetenciáiknak a kialakulását legalább olyan mértében befolyásolja az, ahogyan őket a képzés során tanítják, mint az, amit nekik a hatékony tanításról tanítanak. Ebből a tényből nyilvánvalóan következik, hogy a tanárképzőknek professzionális oktatóknak, a korszerủ oktatási eljárások, módszerek, szemlélet hordozóinak kell lenniük. Jelenleg a legtöbb európai országban, köztünk hazánkban is gyakorta előfordul, hogy a tanárképzők kiváló szakemberei szaktárgyuknak, de a tanításra nincsenek felkészítve. Előfordul az is, hogy tanári diplomával sem rendelkeznek. De a tanári diplomával rendelkezők esetében is fennáll annak a veszélye, hogy egy ma már túlhaladott pedagógiai szemléletet és gyakorlatot képviselnek. Mindezek a tények aláhúzzák a tanárképzők képzésének a fontosságát, $\mathrm{s}$ ezt megelőzően az eredményes tanárképzéshez szükséges kompetenciák (sztenderdek) meghatározását.

Az első jelentős lépést ebben a tekintetben a holland tanárképzők tették, akik az ATEE 2005. évi 30, konferenciáján az alábbi kompetenciákat sorolták fel:

1. Alapozás: a tanárképzőktől elvárt alapvető attitüdök és alapelvek:

- nyitott másokkal szemben, jó figyelő, befogadó; elkötelezett; a problémák tapintatos és diplomatikus megoldására törekszik;

- a résztvevők fejlesztésére összpontosít, és felelőssé teszi őket saját fejlődésük előmozdításában;

- a kiváló tanítást, gyakorlatot modellezi, annak megfelelően tanít, amit a jó tanításról mond.

2. Interperszonális kompetenciák:

- biztonságos munkalégkört teremt;

- empatikus hallgatóival szemben, a szükségletekhez mérten szabadságot ad nekik, követi munkájukat, s konfrontálódik velük.

3. Pedagógiai kompetenciák:

- a tanárjelöltek számára inspiráló, stimuláló tanulási feltételeket teremt;

- arra serkenti a hallgatókat, hogy reflektáljanak saját tapasztalataikra, és értékeljék saját tanári képességeiket, felkészültségüket.

4. Szervezési kompetenciák:

- $\quad$ saját munkáját és szabadidejét jól szervezi;

- szükség esetén improvizál. 
5. Együttmüködés a kollégáival:

- együttmüködik a többiekkel multidiszciplináris teamek keretében;

- aktívan közremüködik az intézmény nézetrendszerének és politikájának kialakításában és megvalósításában.

6. Szélesebb kontextusban is tevékenykedik

- megfelelö kapcsolatrendszerrel rendelkezik, s azt naprakész állapotban tartja;

- közremüködik az oktatás-nevelés és a tanárképzés megújításban, az ezekről folyó vitákban.

7. Munkálkodik a saját fejlődésén:

- rendszeresen reflektál saját pedagógiai szemléletmódjára, tanítási tevékenységére, valamint a tanulókkal, kollégákkal és egyéb személyekkel kapcsolatos viselkedésére;

- a saját szakterületén, illetve a neveléstudomány területén elért új eredményeket felhasználja hallgatóinak szakmai felkészítése és a tanárok folyamatos szakmai fejlődése érdekében (Falus, 2005/b).

Az elmúlt öt évben a tanárképzők képzése felé jelentős figyelem fordult. Az európai kutatások, tapasztalatok összegzését tartalmazza egy 2009-ben megjelent tanulmánykötet (Swennen and Klink, 2009). Az EU Teachers and Trainers Cluster 2010 nyarára tervezi egy a tanárképzők képzésével foglalkozó PLA szervezését. Hazánkban a TÁMOP pályázatok keretében megkezdődött a tanárképzők képzése, továbbképzése.

\section{Irodalom}

3/2009. (IV. 24.) Korm. rendelet a pedagógus-továbbképzésröl, a pedagógus-szakvizsgáról, valamint a továbbképzésben részt vevők juttatásairól és kedvezményeiröl szóló 277/1997. (XII. 22.) Korm. rendelet módosításáról MK 2009/57. 2009. 07. 31.

A tanárképzés képesitési követelményei (2006): ELTE PPK, kézirat.

A tanári mesterszakok képzési és kimeneti követelményei (2006). Az oktatási miniszter 15/2006. sz. rendelete http://www.oh.gov.hu/jogszabalyok/miniszteri_rendeletek (letöltve: 2010. 06. 08.)

A Tanács és a tagállamok kormányainak a Tanács keretében ülésezö képviselöi által elfogadott következtetések (2007. november 15.) a tanárképzés minőségének javításáról. Az Európai Unió Hivatalos Lapja, 2007. 12.12. C300/6-9.

Ajánlás a tanári mesterszak összefüggö szakmai gyakorlati félévének tartalmára 2009. http://www.okm.gov.hu/felsooktatas/kepzesi-rendszer/kepzesi-kimeneti (letöltve: 2010. 04. 05.)

Common European Principles for Teacher Competences and Qualification 2005, kézirat. Az IKT, Kulcskompetenciák és a Tanárok és Képzök klaszter közös szemináriuma, 2009. 06. 24. 
Barone et al. (1996): A Future for Teacher Education: Developing a Strong Sense of Professionalism, In: Sikula és mtsai (szerk.): Handbook of Research on Teacher Education. MacMillan, New York, 1108-1149.

Bleach, K. (1999): The Induction and Mentoring of Newly Qualified Teachers. A New Deal for Teachers, David Fulton, London.

Falus Iván (2005a): Képesítési követelmények - kompetenciák - sztenderdek. Pedagógusképzés, 1. sz. 1-16.

Falus Iván (2005b): Sztenderdek tanárok és tanárképzők számára. Pedagógusképzés, 4. sz. $143-146$.

Falus Iván (2005c): A pedagógusképzés vége. In: Buda András - Kiss Endre (szerk.): Interdiszciplináris pedagógia és az elvárások forradalma. A III. Kiss Árpád Emlékkonferencia előadásai. Kiss Á. Archívum Kvt. - DE Neveléstudományi Tanszék, Debrecen, 231-241.

Falus Iván (2006): A tanári tevékenység és a pedagógusképzés új útjai. Gondolat Kiadó, Budapest.

Falus Iván - Kotschy Beáta (2006): Kompetencia alapú tanárképzés: Divatos jelszó vagy a megújulás eszköze? Pedagógusképzés, 3-4. sz. 67-78.

Falus Iván (2008): Javaslat a pedagógus alap-, bevezetö- és továbbképzés, a pedagógusértékelés, a kompetencia alapú pedagógus elömenetel egységes rendszerének kidolgozására. (kézirat)

Falus Iván - Kotschy Beáta (2008): A pedagógusképzésre vonatkozó európai törekvések és ezek hatása a magyarországi gondolkodásra. In: Krémó Anita (szerk.): Oktatás és képzés 2010. Mühelybeszélgetések 2007. Oktatási és Kulturális Minisztérium, Budapest, 93-106.

FitzPatrick, J., Soulsby, D.(2002): Proposal for revised induction standards. TTA, London. Guidance (2002): The Induction Period for Newly Qualified Teacher. DfES 82/2001.

Into Induction 2003, Teacher Training Agency, London, 21.

Kárpáti Andrea (2008): Tanárképzés, továbbképzés. In: Fazekas Károly, Köllő János, Varga Júlia (szerk.): Zöld könyv a magyar közoktatás megújításáért. Ecostat, Budapest, 193-215.

Kimmel Magdolna (2006): A tanárképzés problémái konstruktivista értelmezési keretben. In: Falus Iván (szerk.): A tanárrá válás folyamata. Gondolat Kiadó, Budapest, 11-45.

Kotschy Beáta (2006): A pedagógusok szakmai fejlődésének új perspektívái: a szakmai fejlesztő iskolák. In: Falus Iván (szerk.): A tanárrá válás folyamata. Gondolat Kiadó, Budapest, 156-176.

Krull, E. (2004): Kezdő tanárok és tanárjelöltek gyakorlatának támogatása: a mentorok szerepe, kiválasztása és képzése. Pedagógusképzés, 3. sz. 63-77.

Learning, Innovation and ICT. Lessons learned by the ICT cluster Education \& Training 2010 programme.

http://www.kslll.net/Documents/Key\%20Lessons\%20ICT\%20cluster\%20final\%20ver sion. pdfl (letöltve:2010.02.08.)

Report of a Peer Learning Activity. Dublin, 26-29 September 2005. 
$C P D$ for teachers and trainers.

http://ec.europa.eu/education/policies/2010/doc/reportpeer4_en.pdf(letöltve: 2010.04.05.)

Report of a Peer Learning Activity: Schools as learning communities for their teachers. The Hague, the Netherlands, 28 May to 1 June 2006.

http://ec.europa.eu/education/policies/2010/doc/reportpeer4_en.pdf(letöltve: 2010.04.05.)

Report of the Peer Learning Activity. Oslo, May 2007.

How can Teacher Education and Training policies prepare teachers to teach effectively in culturally diverse settings? Cluster 'Teachers and Trainers'

http://www.kslll.net/Documents/PLA_Teaching effectively in culturally diverse settings (2010. 04. 05.)

Report of a Peer Learning Activity. Copenhagen / Malmö, 7-11 October 2007.

Relationships between Teacher Education Institutions and schools. http://ec.europa.eu/education/policies/2010/doc/reportpeer4_en.pdf(letöltve: 2010.04.05.)

Snoek, M. et al. (2009): Developing Coherent and System-wide Induction Programmes for Beginning Teachers - a handbook for policymakers. EU Teachers and Trainers Cluster. (kézirat)

Swennen, A., Klink, M. van der (eds.) (2009): Becoming a teacher educator. Theory and practice for teacher educators. Dordrecht, Springer.

Szivák Judit (1999): A kezdö pedagógus tapasztalatszerzö folyamatának vizsgálata. $\mathrm{PhD}$ értekezés, kézirat, ELTE, Budapest.

Szivák Judit (2004): A kezdő pedagógus. In: Falus Iván (szerk.): Didaktika. Nemzeti Tankönyvkiadó, Budapest, 490-512.

Teacher Induction Scheme 2004/2005. (2004) www.scotland.gov.uk/library5/education (letöltve: 2004. 02. 03.)

Tickle, L. (2000): Teacher Induction: The Way Ahead. Open University Press, Buckingham, Philadelphia.

Totterdell, M. et al. (2002): Evaluation of the Effectiveness of the Statutory Arrangements for the Induction of Newly Qualified Teachers. Queens printer, Norwich.

TTA (1998): National Standards for Qualified Teacher Status. Teacher Training Agency, London.

TTA (1999): Career Entry Profile for Newly Qualified Teachers. Teacher Training Agency, London.

Watkins, M. (2009): Alternative pathways into teaching. A Teachers and Trainers Cluster, 2009. június 24-én tartott ülésén elhangzott elöadás. 